\title{
Working
}

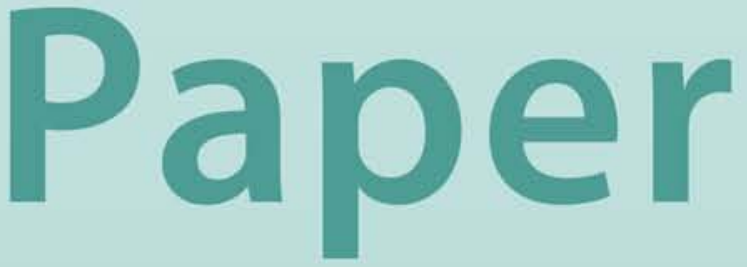


Determinants of Interest Rate Pass-Through: Do Macroeconomic Conditions and Financial Market Structure Matter?

Nikoloz Gigineishvili 


\title{
IMF Working Paper
}

\section{Determinants of Interest Rate Pass-Through: Do Macroeconomic Conditions and Financial Market Structure Matter?}

\section{Prepared by Nikoloz Gigineishvili ${ }^{1}$}

\author{
Authorized for distribution by Johannes Mueller
}

JuQ 2011

\begin{abstract}
Numerous empirical studies have found that the strength of the interest rate pass-through varies markedly across countries and markets. The causes of such heterogeneity have attracted considerably less attention so far. Unlike other studies that mainly focus on small groups of mostly developed and emerging markets in the same region, this paper expands the cross-sectional coverage to 70 countries from all regions, including low income, emerging and developed countries. It uses a wide range of macroeconomic and financial market structure variables to uncover structural determinants of pass-through. The paper finds that per capita GDP and inflation have positive effects on pass-through, while market volatility has a negative effect. Among financial market variables exchange rate flexibility, credit quality, overhead costs, and banking competition were found to strengthen pass-through, whereas excess banking liquidity to impede it.
\end{abstract}

JEL Classification Numbers: C22, C31, E43, E44, E58, G21

Keywords: Interest rate pass-through, transmission mechanism, monetary policy

Author’s E-Mail Address:ngigineishvili@imf.org

\section{This Working Paper should not be reported as representing the views of the IMF.}

The views expressed in this Working Paper are those of the author(s) and do not necessarily represent those of the IMF or IMF policy. Working Papers describe research in progress by the author(s) and are published to elicit comments and to further debate.

\footnotetext{
${ }^{1}$ The author is grateful to Jean Le Dem, Arto Kovanen, Marco Pani, Patrick Imam, Robert Tchaidze, David Lezhava, Balazs Egert, Deniz Igan, Francis Vitek, and the members of the Monetary Policy Network of the IMF's African Department for valuable comments and suggestions.
} 
1. INTRODUCTION

2. Monetary Transmission Mechanism and Interest Rate Pass-Through $\underline{4}$

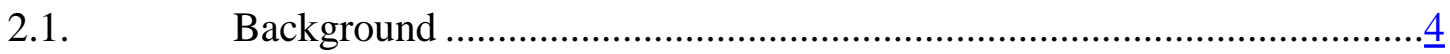

2.2. Model of Interest Rate Pass-Through.................................................. $\underline{5}$

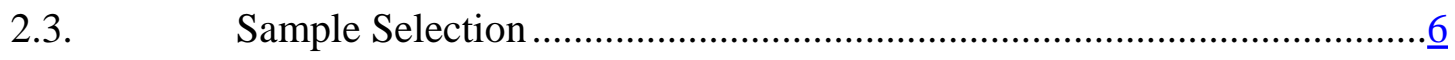

2.4. Pass-Through Estimates …..........................................................

3. Determinants of Interest Rate Pass-Through ............................................................... $\underline{8}$

3.1. Brief Summary of Literature .........................................................

3.2. Variable Selection and Methodology ….............................................

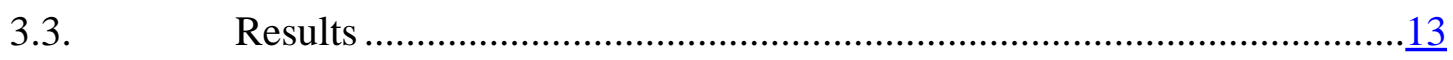

4. Conclusions and Policy Implications.................................................................... 17

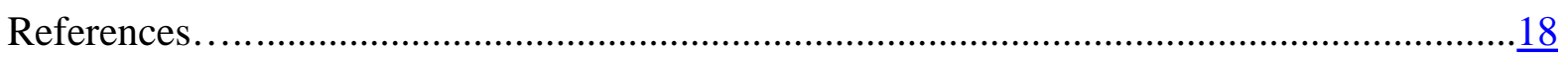




\section{INTRODUCTION}

One of the pillars of modern monetary policymaking is good understanding of monetary transmission - a mechanism that transmits central bank policy actions to the real sector and allows the central bank, at least in theory, to steer the economy in the desired direction. Channels of transmission and its strength and speed determine the effectiveness of monetary policy. The mechanism is complex, however, and can take various forms depending on a host of factors, including macroeconomic conditions, financial market structure and development, and the regulatory framework.

Among various channels of monetary transmission, the interest rate channel is the most traditional mechanism and has been subjected to intense scrutiny. It started to attract even more attention with the growing popularity of inflation targeting as a monetary policy framework, for which the interest rate channel is one of the main pillars. It is essential for an inflation targeter central bank to understand how, by how much, and over what period changes in policy interest rates affect inflation.

The importance of transmission and the interest of policymakers in understanding its functioning have given rise to numerous theoretical studies over the past several decades to uncover its properties. More recently, a large volume of empirical research has been devoted to investigating qualitative and quantitative properties of interest rate pass-through - a key component of monetary transmission that describes how changes in central banks' policy rates transmit to longer-term retail interest rates on loans and deposits. Numerical estimates of pass-through coefficients diverge significantly across countries, markets, and time periods, implying that retail pricing by banks in different countries and markets reacts differently to monetary policy impulses. ${ }^{2}$

However, the literature on determinants of interest rate pass-through is relatively scarce and little is known about the factors that cause these differences. From this point of view, the black box, as Bernanke and Gertler (1995) referred to transmission, remains an unsolved puzzle. Knowing what factors drive bank behavior and market responses to central bank actions would have valuable implications for strengthening monetary policy efficiency. This knowledge could provide important input for the choice of a monetary framework, including intermediate targets and policy instruments, and help identify measures that are needed to improve it.

This paper is intended to contribute to the debate. The main objective is to explain crosscountry differences in pass-through with country-specific structural and macroeconomic characteristics. The paper first estimates country-specific pass-through coefficients using a fairly standard approach of autoregressive distributed lags. Unlike other studies that mainly rely on small groups of countries, this paper expands the coverage to seventy economies from all parts of the world and of all levels of development. The second part of the paper

\footnotetext{
${ }^{2}$ For a comprehensive survey of literature see Egert and MacDonald (2009).
} 
relates these coefficients to macroeconomic variables and indicators of the financial market structure. It finds that that per capita GDP and inflation have positive effects on pass-through, while market volatility has a negative effect. Among financial market variables credit quality, overhead costs, and banking competition were found to strengthen pass-through, whereas excess banking liquidity to impede it. It also finds that small island states, countries in Middle East and Central Asia, and economies with fixed exchange regimes tend to have weaker pass-through. Policy implications follow.

\section{Monetary Transmission Mechanism and Interest Rate Pass-Through}

\subsection{Background}

The views of the monetary transmission mechanism have converged into four main channels (Mishkin, 1996). The common feature of all the channels is that they all transmit policy decisions to aggregate demand and/or supply through financial markets. The difference is the type of financial market that is as a medium of pass-through. At the early stages of financial development, the exchange rate channel is thought to play a key role. In countries with undeveloped capital and money markets, foreign exchange is perceived as the single most liquid and inflation proof asset. The price of this asset—-the exchange rate — quickly reacts to changes in monetary policy, feeding into demand and supply and ultimately to output and prices. Other channels of transmission - the interest rate channel, the asset price channel, and the credit channel - tend to dominate in more developed markets. The interest rate channel transmits changes in policy rates to retail lending and deposit rates via money markets, causing adjustments to investment and savings decisions. The asset price channel works in a similar way through the prices of other assets such as bonds, stocks and real estate. A policy-induced change in interest rates alters the effective cost of capital and the net worth of households and enterprises, followed by adjustments in consumption and investments, and consequently in aggregate demand and prices. Finally, the credit channel transmits monetary policy signals by influencing credit supply rather than interest rates. ${ }^{3}$ This channel would normally play an important role in markets with limited substitutability between loans and other forms of financing for borrowers, and between loans and other financial assets for banks (Egert and MacDonald, 2009).

The channels of transmission could complement each other and work simultaneously. The recent US Federal Reserve Bank policy of quantitative easing (QE) was an attempt to leverage the asset price and credit channels to stimulate growth in the United States. With the federal funds' rate already at close to zero, the interest rate channel had reached its limits in easing the monetary stance, prompting the Fed to resort to the unconventional policy of QE. By purchasing government bonds and other financial assets, the Fed aimed at lowering yields (pushing asset prices up) and injecting a large amount of liquidity in banks in to boost lending. However, the effectiveness of QE remains to be seen.

\footnotetext{
${ }^{3}$ Bernanke and Gertler (2005) view the credit channel as an enhancement of the interest rate channel, rather than a stand-alone mechanism of transmission.
} 
This paper focuses on the interest rate channel of monetary transmission, whereby interest rate pass-through provides a critical link between monetary policy decisions and their target variables. The idea is that changes in central bank policy rates cause movements in market rates (money market, treasury bills), starting from short maturities and moving to longer maturities through the yield curve. Next, the changes in market rates pass through to commercial bank lending and deposit rates, which in the final phase of monetary transmission affect savings, investments and consumption, and therefore aggregate demand and ultimately prices. Because central banks normally operate at the lower end of the yield curve, the impact of policy changes on money market rates is usually strong and immediate. ${ }^{4}$ The second phase of the process-market-to-retail interest rate pass-through-is more diverse, and is the main subject of this study.

\subsection{Model of Interest Rate Pass-Through}

Market-to-retail pass-through can be explained using the cost of funds approach (De Bondt, 2002), which applies a standard marginal cost pricing model to financial markets. The underlying theory is that money market rates reflect marginal or opportunity costs of funds because banks rely on them for short-term borrowing. They also represent opportunity cost of deposits for households and enterprises given the alternative possibility of investing in money markets or short-term government securities. The pricing of banks' retail products will also include a premium for maturity and risk transformation involved in their activities. The theory implies a positive relationship between market rates and retail lending and deposit rates, which can be formalized in the following markup pricing model:

$i^{R}=\alpha+\beta \cdot i^{M}$

where $i^{R}$ and $i^{M}$ are retail and market rates respectively; $\beta$ is a long-run pass-through coefficient, and $\alpha$ is a markup. If markets are perfect (full information and perfect competition) and banks risk-neutral, $\beta$ would equal 1 , implying complete pass-through or a unit interest rate elasticity of demand for deposits and loans (Coricelli, Egert, and McDonald, 2006). Empirical studies, however, suggest that in practice, pass-through is usually incomplete with $\beta<1$, and varies widely by countries and markets.

Equation (1) represents the long-run equilibrium relationship. The out-of-equilibrium adjustment is best described by the error-correction process:

\footnotetext{
${ }^{4}$ However, depending on the slope and stability of the yield curve, longer-term market rates may react differently than short-term rates. If investors are risk-neutral and markets efficient, long-term rates derive as an average of expected short-term rates. The yield curve would be steeper if investors are risk-averse and demand a liquidity premium on longer maturities. Finally, in segmented markets, interest rates at the two ends of the yield curve could be disconnected, resulting in the breakdown of the transmission mechanism.
} 
$\Delta i_{t}^{R}=\mu+\rho\left(i_{t-1}^{R}-\alpha-\beta i_{t-1}^{M}\right)+\gamma \Delta i_{t}^{M}+\varepsilon$

where $\rho$ measures the speed of adjustment, and $\gamma$ is a short-run pass-through coefficient.

Equation (2) can be further expanded with more short-run dynamics to arrive at the following autoregressive distributed lag form:

$\Delta i_{t}^{R}=\mu+\rho\left(i_{t-1}^{R}-\alpha-\beta i_{t-1}^{M}\right)+\sum_{k=0}^{n} \gamma_{k} \Delta i_{t-k}^{M}+\sum_{k=1}^{n} \delta_{k} \Delta i_{t-k}^{R}+\varepsilon$

or by substituting $\Delta i_{t}=i_{t}-i_{t-1}$ and grouping similar terms,

$i_{t}^{R}=\theta+\sum_{k=0}^{n+1} \beta_{k} i_{t-k}^{M}+\sum_{k=1}^{n+1} \alpha_{k} i_{t-k}^{R}+\varepsilon$

In this equation, $\beta_{k}$ 's are short-run interaction elasticities, while $\alpha_{k}$ 's reflect persistence of retail interest rates. By estimating equation (3), the long-run interest rate pass-through coefficient can be calculated as

$\beta=\left(\sum_{k=0}^{n+1} \beta_{k}\right) /\left(1-\sum_{k=1}^{n+1} \alpha_{k}\right)$

The mark-up pricing relationship between market and retail rates implies that $\beta$ should be positive. It also requires that the following conditions be satisfied (Weth, 2002):

$\sum_{k=0}^{n+1} \beta_{k}>0$

that is, the cumulative impact of contemporary and lagged market rates on retail rates is positive; and

$\sum_{k=1}^{n+1} \alpha_{k}<1$

which is a stability condition implying convergence of retail interest rates.

\subsection{Sample Selection}

The data set includes 81 countries and comprises low income, emerging, and developed economies for which money market and retail lending interest rate series were available on a monthly basis from December 2005 to March 2010. A period of only about 4 years was chosen to minimize structural changes, yet it is long enough to provide a sufficient number of observations. Three-month treasury bill rates were used for money market rates, and interest 
rates on one- to two-year corporate loans in domestic currency were used for retail lending rates. For some countries t-bill rates were not available. In such cases, three-month interbank lending rates were used instead. For countries where maturity breakdown of loans was unavailable, average lending rates were used for retail rates. The data were obtained from the IMF’s International Financial Statistics database and individual country central bank publications. Countries with controlled or nearly fixed interest rates (either money market or retail rates) were excluded.

All variables were log-differenced to smooth out time series and remove unit roots, which were found to be present in all interest rate series. Equation (3) was then estimated individually for each country with two-month lags. Omitted were seven cases that failed to meet conditions (5) and (6), and four cases that produced very poor goodness of fit $\left(R^{2}<0.1\right)$ and had all short-run coefficients $\beta_{k}$ statistically insignificant. This filtering reduced the sample size to 70 countries.

In the out-of-equilibrium representation (equation (3)), retail rates respond to market rates in the same period $(k=0)$ or with a lag $(k=1,2)$. In most cases the contemporaneous interaction parameter $\beta_{0}$ was found to be significant, and used as a measure for the short-run passthrough elasticity. For the rest, the first statistically significant lagged $\beta_{k}\left(\beta_{1}\right.$ or $\left.\beta_{2}\right)$ was used instead. Long-run $\beta$ coefficients were obtained using equation (4).

\subsection{Pass-Through Estimates}

The estimation results are presented in Figure 1, which groups countries by region, size, level of development, and exchange regime. ${ }^{5}$ Small island states have also been included as a separate group for reasons that will become apparent in the following section. The figure confirms the results of other studies that the size of pass-through varies markedly across countries. From the regional perspective, Middle East and Central Asia appears to have the weakest pass-through, short-run and long-run, possibly affected by rules of Islamic banking, which restricts payment of interest. On the other hand, North America (United States and Canada) exhibit significantly higher pass-through than other groups, reflecting highly competitive and developed financial markets. Micro states, including small island economies, tend to have weaker pass-through, which is not surprising given that financial markets in small economies are normally shallower and less developed. More advanced economies

\footnotetext{
${ }^{5}$ MEA stands for Middle East and Central Asia, LAT for Latin America, ASIA for Asia, AFR for Sub-Saharan Africa, and EUR for Europe. The US and Canada were grouped together in North America owing to the difficulty of including them in any other regional group; micro states are defined as countries with population less than 2 million (Imam, 2009). The exchange rate regime definition rests on IMF's Annual Report on Exchange Arrangements and Exchange Restrictions (2009), with free-floating, floating, and other managed arrangements classified as flexible and the rest as fixed regimes. Classification by level of development is based on IMF's World Economic Outlook Database (April 2010); low-income countries are those that are eligible for financing from the IMF’s Poverty Reduction and Growth Trust.
} 
appear to have stronger pass-through in the long-run, but not in the short-run, implying stronger persistence of market interest rates (higher $\Sigma \alpha_{k}$ in equation (4)). The figure also shows that pass-though is stronger in countries with flexible exchange regimes, and that it is stronger in the long run than in the short run.

Figure 1. Interest Rate Pass-Through Coefficients

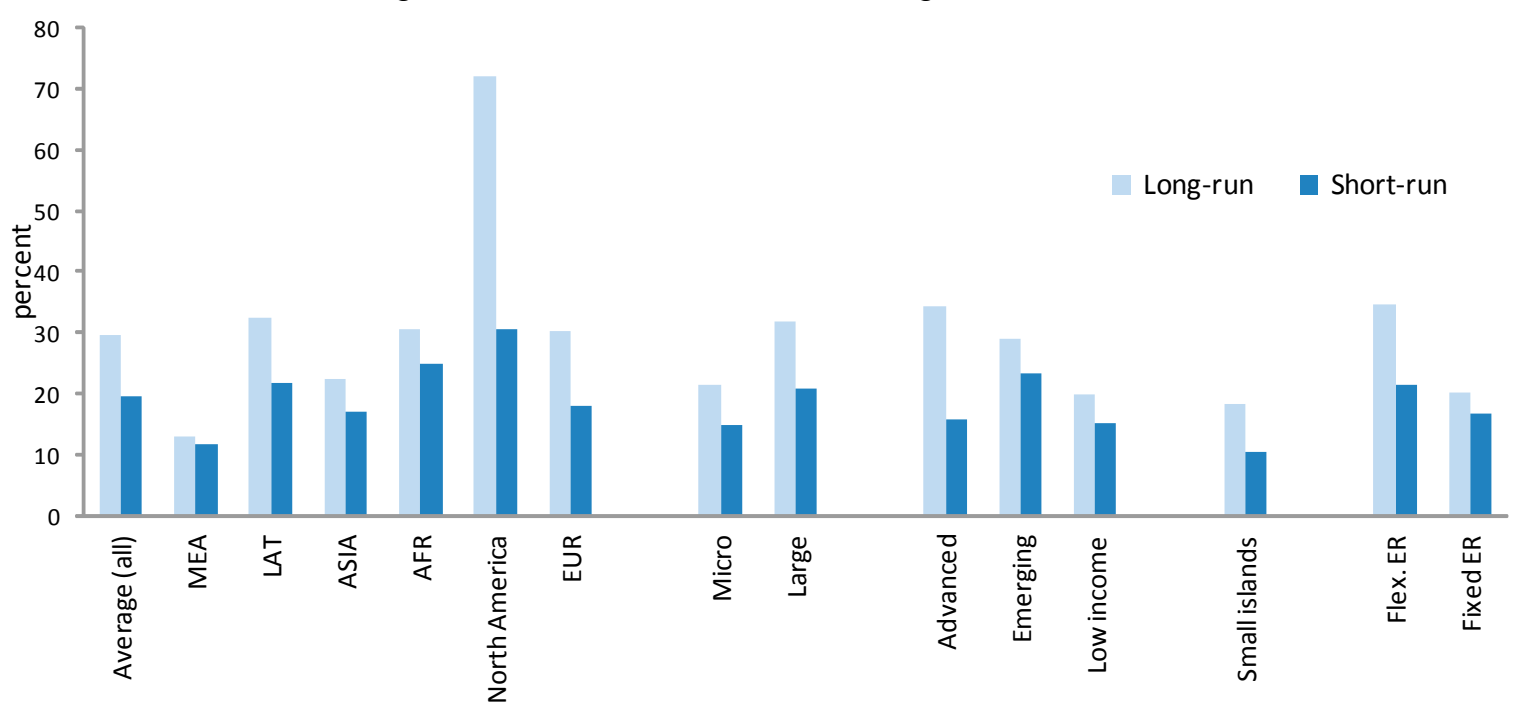

\section{Determinants of Interest Rate Pass-Through}

\subsection{Brief Summary of Literature}

As noted in the introduction, a large volume of research has been devoted to heterogeneity of interest rate pass-through in various countries and markets. The analysis of structural determinants of these differences, however, has received considerably less attention, possibly because of difficulties in compiling consistent cross-country series of macroeconomic and structural variables. The existing literature has focused mainly on small groups of countries in the same region or different market segments in a given country, limiting the number of cross sections and therefore the predictive power of econometric methods. The studies differ not only by country selections, but also by time periods covered, the sets of explanatory variables used, and the methodologies employed. Nevertheless, the findings of different papers exhibit similarities.

In their pioneering work on determinants of interest rate pass-through covering 31 developed and emerging economies, Cottarelli and Kourelis (1994) found that a higher inflationary environment, capital mobility, and money market development (proxied by volatility of money market rates or by the size of the market for short-term securities) result in a stronger pass-through. Similar results for inflation and money market volatility were obtained for different groups of European countries by Mojon (2000), and Sander and Kleimeier (2004b). 
Literature appears unanimous about the positive role of competition in the banking system for the pass-through process. Different researchers have used different measures of competition: Cottarelli and Kourelis used concentration of banking sector and a measure of private ownership of banks, Mojon used an index capturing the degree of banking deregulation in Europe, and Sorensen and Werner (2006) used banking concentration and market power measured by return on equity (ROE), also for a group of European countries. But all came to the conclusion that competition tends to improve pass-through. ${ }^{6}$

Apart from these commonly used variables, Sorensen and Werner report a negative relationship of pass-through elasticities with banks' excess liquidity, excess capital, rigidity of bank funding costs (share of deposits in total liabilities), and interest rate risk (measured by maturity mismatch). They also find that portfolio diversification (share of noninterest income in total income) and credit risk (loan provisioning) improve pass-through. Sander and Kleimeier find that the health of the banking sector, inversely proxied by nonperforming loans as a percent of total loans, reduces interest rates stickiness. Mojon reports that high operating costs, measured as staff costs to gross income, impede pass-through.

Summary of Literature Results: Impact on the Pass-Through

\begin{tabular}{|c|c|c|c|c|c|c|c|c|c|c|c|c|}
\hline & Inflation & $\begin{array}{l}\text { Capital } \\
\text { Mobility }\end{array}$ & $\begin{array}{r}\text { Market } \\
\text { Volatility }\end{array}$ & Competition & $\begin{array}{l}\text { Excess } \\
\text { Liquidity }\end{array}$ & $\begin{array}{l}\text { Excess } \\
\text { Capital }\end{array}$ & $\begin{array}{l}\text { Rigidity of } \\
\text { Funding }\end{array}$ & $\begin{array}{c}\text { Interest } \\
\text { Rate Risk }\end{array}$ & $\begin{array}{c}\text { Portfolio } \\
\text { Diversification }\end{array}$ & $\begin{array}{c}\text { Credit } \\
\text { Risk }\end{array}$ & NPL & $\begin{array}{c}\text { Operating } \\
\text { Costs }\end{array}$ \\
\hline Cottarelli and Kourelis & + & + & - & + & & & & & & & & \\
\hline Mojon & + & & - & + & & & & & & & & - \\
\hline Sander and Kleimeier & + & & - & - & & & & & & & + & \\
\hline Sorensen and Werner & & & & + & - & - & - & - & + & + & & \\
\hline
\end{tabular}

\subsection{Variable Selection and Methodology}

The main hypothesis in what follows is that cross-country differences in long-run passthrough are explained by structural characteristics of countries, specifically by macroeconomic conditions and the financial market structure. Unlike other studies, this paper expands the cross-sectional coverage to 70 countries from all regions, including low income countries and small island economies, which allows for more robust analysis and regional comparison. It also uses a broader range of explanatory variables, and focuses on a recent and relatively short time period, which limits the probability of major structural breaks.

To establish relationships, the pass-through coefficients obtained in the previous section were regressed on different sets of explanatory variables to identify those that are statistically significant, have a meaningful sign, and produce good overall fit.

\footnotetext{
${ }^{6}$ Sander and Kleimeier (2004b) used foreign bank participation as a proxy for competition, but their results yield a negative and significant coefficient, which the authors find implausible and surprising.
} 
The selection of cross-sectional series was driven by data availability. ${ }^{7}$ In addition to size, geographic region, level of development, and exchange regime which appear to matter in Figure 1, other macroeconomic variables tested include GDP growth, inflation, and market interest rates and their volatility. From the financial sector indicators various proxies were used to capture possible impacts of the size of the banking system (total assets and liabilities, private sector credit, and deposits, all as a share of GDP), bank capitalization (capital to total assets and capital to risk weighted assets), asset quality (non-performing loans to total loans), profitability and cost structure (returns on equity and assets, net interest margin, cost-toincome ratio, overhead costs to total assets), and liquidity (liquid assets to short-term liabilities, and to total assets). All variables are averages of available annual data for 20062009 with the exception of average money market interest rates and their volatility, which were calculated with monthly data over the same period. Market volatility is defined as standard deviation of market interest rates divided by average rates. In addition, the dataset includes dummy variables for geographic region, country size and exchange regime. ${ }^{8}$ The distribution of selected macro and financial sector variables by country groups is presented in Figures 2 and 3.

\footnotetext{
${ }^{7}$ Data were compiled from the following sources: International Financial Statistics of the IMF; the IMF's World Economic Outlook, Spring 2010; World Bank Financial Development and Structure Database (2010); and IMF Country Reports.

${ }^{8}$ The definition of exchange rate regimes is based on the IMF's 2009 Annual Report on Exchange Arrangements and Exchange Restrictions. For this paper, free-floating and floating regimes were grouped into a flexible regime, and the rest into a fixed regime. The exchange regime dummy is set to equal one for flexible regimes and zero for fixed.
} 
Figure 2: Macroeconomic Variables
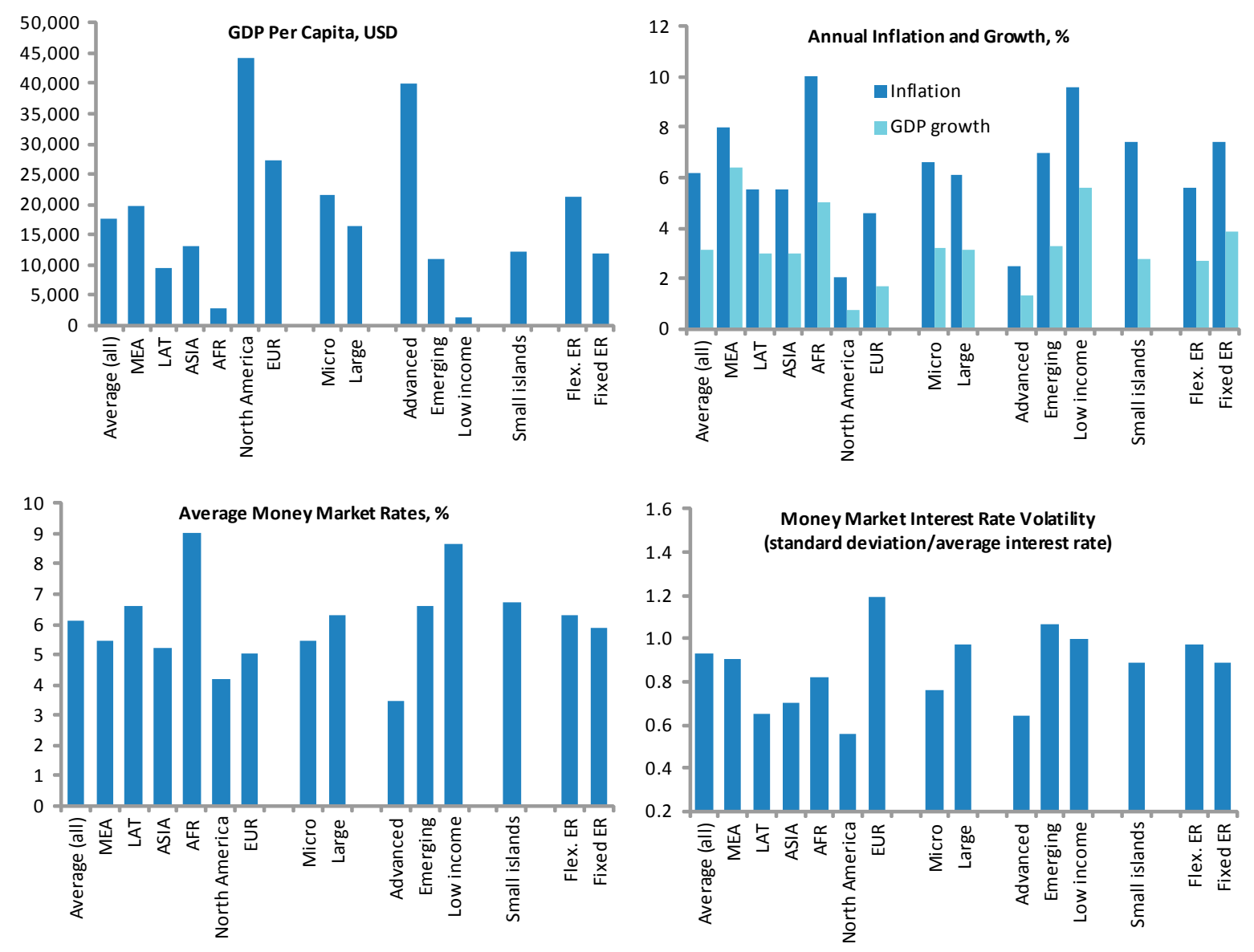
Figure 3: Financial Sector Indicators
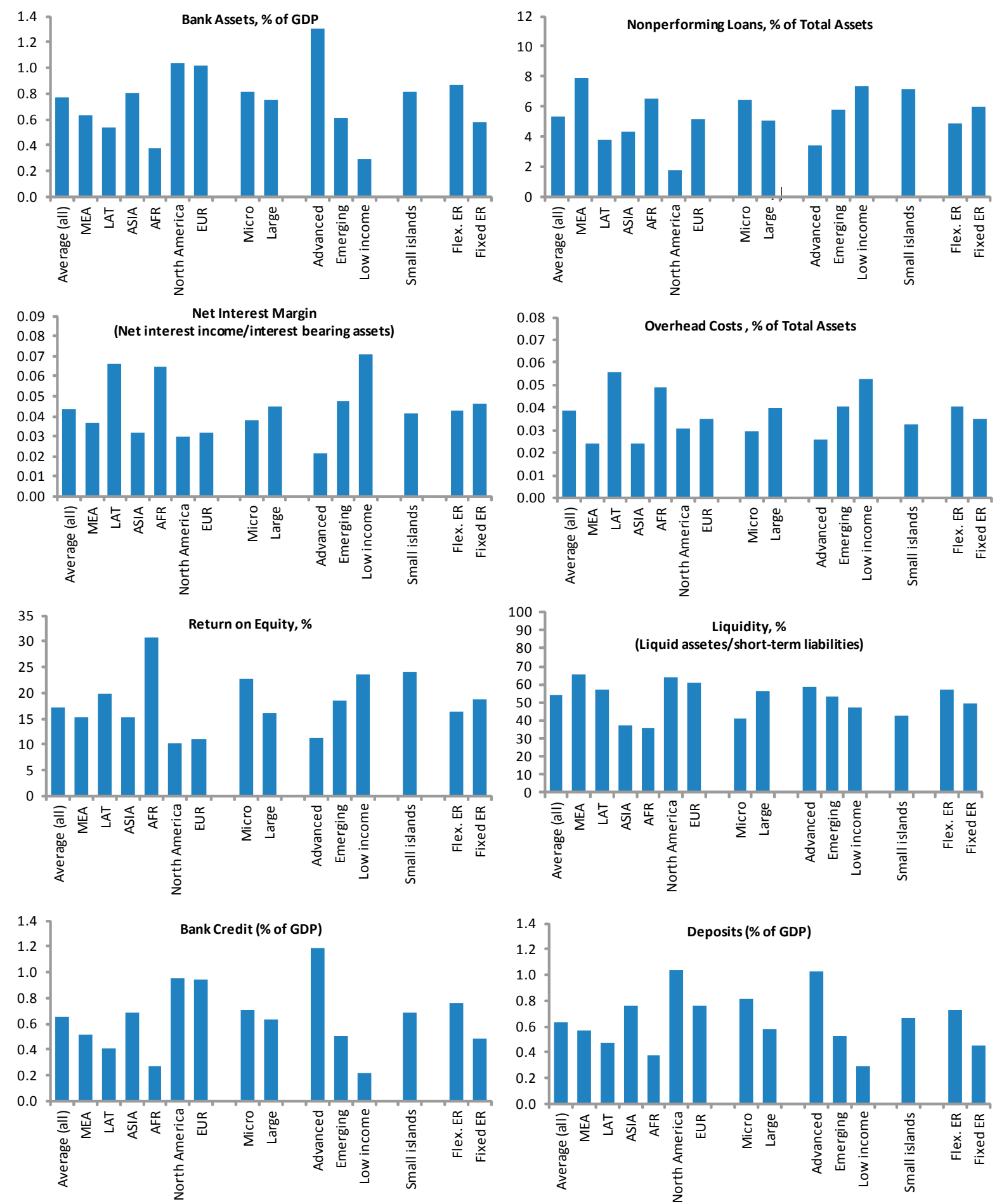
Regressions were performed separately for macroeconomic and financial sector variables, though some variables feature in both subsets. This was done for two reasons. The first was to preserve degrees of freedom, given a relatively small sample size. Because not all variables were available for all the countries, the inclusion of additional regressors would further reduce the effective sample size, while increasing a number of estimated parameters. The second reason was to avoid multicollinearity problems owing to the presence of strong correlations between macro and some financial sector indicators. In most cases macroeconomic variables became insignificant when used jointly with financial sector variables in the same regression, possibly implying that the latter were capturing the impact of the former.

The search for a specification has led to the following equations:

$\beta_{i}=$ const $+\gamma_{1}$ income $+\gamma_{2}$ inf $+\gamma_{3}$ volat $+\gamma_{4}$ Island $+\gamma_{6}$ MEast $+\partial$

$\beta_{i}=$ const $+\gamma_{1}$ liq $+\gamma_{2}$ overhead $+\gamma_{3} N P L+\gamma_{4} R O E+\gamma_{6}$ volat $+\gamma_{6} E R+\gamma_{6}$ MEast $+\partial$

where income is per capita GDP, inf is annual CPI inflation, volat is a measure of market volatility, ${ }^{9}$ Island is a dummy for small-island economies, MEast is a regional dummy for Middle East and Central Asian countries ${ }^{10}$, liq is liquidity of the banking system measured by liquid assets to short-term liabilities, Overhead is banks' overhead costs to total assets, NPL is non-performing loans as a share of total loans, $R O E$ is return on equity, and $E R$ is a binary variable equal to one for flexible and zero for fixed exchange rate regime.

A variation of equation (7) was also estimated where inflation was substituted with average money market interest rates (MMR):

$$
\beta_{i}=\text { const }+\gamma_{1} \text { income }+\gamma_{2} M M R+\gamma_{3} \text { volat }+\gamma_{4} \text { Island }+\gamma_{6} \text { MEast }+\partial
$$

Inflation and interest rates are highly correlated and the former becomes insignificant when both are included in the same regression. However, the fit is better for the specification with interest rates, which also has a larger coefficient than inflation, because interest rates are capturing premiums for inflation as well as credit risk.

\subsection{Results}

The results of the regressions (7), (7') and (8) are presented in the table below.

\footnotetext{
${ }^{9}$ A standard deviation of money-market rates divided by average interest rate.

${ }^{10}$ All other regional dummy variables were found statistically insignificant.
} 
Consistent with Figure 1, per capita GDP has a positive coefficient, implying that more advanced countries have stronger pass-through. This is not surprising since financial markets in wealthier countries are more developed and, therefore, the interest rate channel of monetary transmission should be functioning better.

A priori a positive relationship may also be expected for GDP growth, because in a growing economy loan demand is likely to be less elastic to interest rates. However, real growth turned out insignificant in all specifications, possibly because of its cyclical nature, which banks do not factor in their long-run pricing functions.

Determinants of Pass-Through (Dependant variable is log of long-run pass-through coeficient)

\begin{tabular}{|c|c|c|c|}
\hline Variables & Equation (7) & Equation (7') & Equation (8) \\
\hline Const & $\begin{array}{l}-1.01 \\
(1.0)\end{array}$ & $\begin{array}{l}-1.40 \\
(0.9)\end{array}$ & $\begin{array}{r}7.09 \\
(1.03)\end{array}$ \\
\hline Per capita GDP & $\begin{array}{l}0.37 \text { *** } \\
(0.08)\end{array}$ & $\begin{array}{l}0.37 \text { *** } \\
(0.08)\end{array}$ & \\
\hline Inflation & $\begin{array}{l}0.48 \text { *** } \\
(0.15)\end{array}$ & & \\
\hline Average money market rate & & $\begin{array}{l}0.69 * * * \\
(0.17)\end{array}$ & \\
\hline Liquidity & & & $\begin{array}{l}-0.32 * * \\
(0.14)\end{array}$ \\
\hline Overhead costs & & & $\begin{array}{l}0.69 * * * \\
(0.17)\end{array}$ \\
\hline NPL & & & $\begin{array}{l}-0.32 * * * \\
(0.12)\end{array}$ \\
\hline ROE & & & $\begin{array}{l}-0.211^{* *} \\
(0.09)\end{array}$ \\
\hline Market volatility & $\begin{array}{l}-0.28 * * * \\
(0.08)\end{array}$ & $\begin{array}{l}-0.24 * * * \\
(0.07)\end{array}$ & $\begin{array}{l}-0.19 * * \\
(0.07)\end{array}$ \\
\hline Middle East dummy & $\begin{array}{l}-2.0 \text { *** } \\
(0.37)\end{array}$ & $\begin{array}{l}-1.71 * * * \\
(-0.33)\end{array}$ & $\begin{array}{l}-1.28 * * * \\
(0.47)\end{array}$ \\
\hline Exchange regime dummy & & & $\begin{array}{l}0.63 * * \\
(0.2)\end{array}$ \\
\hline Island & $\begin{array}{l}-0.77 \text { *** } \\
(0.26)\end{array}$ & $\begin{array}{l}-0.64 * * * \\
(0.23)\end{array}$ & \\
\hline R squared & 0.41 & 0.46 & 0.69 \\
\hline \# observations & 69 & 69 & 43 \\
\hline
\end{tabular}

Standard errors in parenthesis.

** denotes significance at 5 percent confidence level. *** denotes significance at 1 percent confidence level. 
The adjustment of lending rates to changes in market rates was found to be stronger in countries with higher inflation and higher market interest rates. A positive correlation of net interest margins with both variables also suggests that when inflation and interest rates are high, banks adjust their lending rates more and increase margins. ${ }^{11}$ As high inflation and interest rates are associated with larger uncertainty, banks in such economies are passing the risk to borrowers at higher rate to maximize risk adjusted returns and protect profitability. Similar to results obtained by Cottarelli and Kourelis, Mojon, and Sander and Kleimeier (2004b), money market rate volatility appears to weaken the pass-through. This variable was found to be statistically significant in all three regression equations. The underlying reasoning is as follows. Banks' response to money market movements is largely determined by the degree to which interest rates carry reliable information about underlying market trends. Volatility, however, introduces uncertainty into market signals, which banks interpret with more caution. Consequently, rather than immediately passing the changes in market rates to customers, they choose to wait until the noise is filtered out. This result is consistent with the above finding on per capita GDP. Indeed, as Figure 2 suggests, advanced economies which tend to have better developed financial markets, exhibit smaller interest rate volatility, and therefore produce more reliable signals.

Similar to Sorensen and Werner (2006), the estimation of equation (8) results in a negative relationship between banks' liquidity and the strength of pass-through. In excessively liquid markets, when all banks are structurally on the same side of the market, interbank trading in short-term funds dries up, and interest rates fail to reflect the true marginal cost of financial resources. Naturally, retail pricing of loans becomes less responsive to money market rates and the connection between the two weakens.

In all model specifications with financial structure variables the coefficient for overhead costs turned out positive and statistically significant at the 1 percent confidence level, implying that overhead costs contribute to the strength of pass-through. This contradicts Mojon, who finds a negative relationship between fixed costs (staff costs as a share of gross income) and the strength of pass-through in the six largest European countries. If, as Mojon argues, large fixed costs are related to an uncompetitive environment, one would indeed expect the respective coefficient to be negative. However, the degree of competition could be better proxied by return on equity (ROE), which is also included among regressors in equation (8). Moreover, ROE appears very weakly correlated with overhead costs (the correlation coefficient is 0.14 ) suggesting that the latter may not be driven by the lack of competition. A possible explanation to the above finding is that at the country level large overheads could be structural in nature, related to obstructive regulatory and legal frameworks, undeveloped financial infrastructure, and information asymmetry. These may include excessive costs originating from burdensome registration requirements, prolonged court litigations, legal obstacles in seizing and liquidating collateral, difficulties in assessing credit worthiness of borrowers and the value of collateral, and so forth. To cover such costs, banks would have to maintain higher interest margins. Indeed, statistical analysis of data shows strong cross-country correlation between overheads and net interest margins (the

\footnotetext{
${ }^{11}$ Net interest margin is measured as a ratio of net interest income to average assets.
} 
correlation coefficient is 0.69). To preserve these margins, an increase in money market rates is likely to induce stronger pass-through to lending rates. When money market rates are declining, it could be argued that banks would be less willing to quickly adjust their lending rates in response. However, if overhead costs of loan origination are substantial, possibly because of information asymmetry, pass-through would still be stronger to allow banks remain competitive, preserve the 'costly' customer base and even expand it at the expense of competitors. Although the result appears quite robust, more analysis is needed to better understand the mechanism through which overhead costs influence pass-through.

Credit quality (lower NPLs) was found to improve pass-through-consistent with the finding of Sander and Kleimeier (2004b). If NPLs reflect the degree of credit risk in a country, the risk premium demanded by banks and therefore lending rates would be higher in countries with higher NPLs. But there is also a reverse relationship: by raising lending rates, say in response to rising short-term rates, banks would attract riskier projects, and would also increase probability of default on existing loans (assuming variable rate loans). This would add to credit risk pushing NPLs even higher and increasing the likelihood of incurring additional losses. Therefore, profit maximizing banks might be less responsive to money market rates when credit quality is already poor. In this case a larger portion of the increase in cost of funds (short-term interest rates) is absorbed by risk premiums, and the pass-through is weaker. High credit risk could also be related to credit rationing, whereby institutional or other constraints to lending induce higher risk-taking at lower rates (Sorensen and Werner), which would also contribute to the sluggishness of pass-through.

High profitability (ROE) of the banking sector, which is often a reflection of inadequate competition and market power, weakens pass-through. This is intuitive because in an uncompetitive environment banks are able to charge higher premiums and deviate from marginal cost pricing. As a result, lending rates become less elastic to changes in costs of funds.

The regression (8) confirms the observation in Figure 1 that exchange rate flexibility contributes to the strength of pass-through. An increase in domestic interest rates would trigger inflow of capital, which under flexible exchange regimes would lead to currency appreciation until yields in domestic and foreign currencies return to balance. Fixed exchange regimes lack such a 'buffer', and unsterilized or partly sterilized capital inflows would translate into larger liquidity and result in downward pressure on interest rates. It should be noted, however, that the binary variable used in this study may not adequately capture the role the exchange regime in interest rate pass-through. Instead of having purely floating or fixed regimes, countries in the sample vary significantly by the degree of exchange rate flexibility. They also differ by openness of their capital accounts. Therefore, more insight could probably be gained by using finer classification of exchange regimes, and introducing variables to reflect the degree of capital account openness. Given the importance of the exchange rate for monetary policy formulation and macroeconomic management in general, this could be an interesting and useful topic for subsequent research.

Finally, as anticipated, Middle Eastern and Central Asian countries and small island economies exhibit more sluggish pass-through. The latter result is also consistent with the 
finding that exchange rate flexibility improves pass-through since most small islands tend to have some form of a fixed exchange regime.

\section{Conclusions ANd Policy Implications}

This paper investigated the role of structural variables, both macroeconomic and financial market related, in determining the strength of interest rate pass-through. Having tested a range of potential explanatory variables, it finds that per capita GDP, inflation, interest rates, credit quality, overhead costs and competition among banks facilitate the pass-through process; market volatility and excess liquidity in the banking system, on the other hand, impede it. Countries with fixed exchange rate arrangements tend to have weak pass-through, and so do Middle Eastern and Central Asian countries and small island states.

As noted in the introduction, these findings have important implications for monetary policy design and choice of a monetary framework. If pass-through is weak and cannot be improved, possibly because a country is a small island state or is a low income economy, which would require considerable time to develop its financial markets and strengthen transmission, a monetary framework that relies on strong interest rate pass-though, such as inflation targeting, may not be an optimal option. Instead, it might be more appropriate for such a country to adopt a framework that uses monetary aggregates, exchange rate or other nominal anchor as an intermediate target.

The results also pose interesting policy challenges for central banks. In most cases the primary objective of monetary policy is to achieve and maintain low inflation, be it defined as a specific inflation target (a point or a range) or more generally as price stability. Clearly, it is in any central bank's interest to strengthen transmission, which provides connection between monetary policy instruments and banks' objectives. The stronger and faster the passthrough, the easier it will be for a central bank to achieve its objective. However, the positive relationship between inflation and the strength of pass-through suggests that by being successful in its key mandate of reducing inflation, a central bank contributes to the weakening of monetary transmission. Similarly, while improving the regulatory and legal environment, promoting information sharing and removing obstacles to banking intermediation could be among objectives of policy makers and financial sector regulators, the resulting reduction in overhead costs would also weaken pass-through making it harder for a central bank to control inflation.

Obviously, these factors should not be viewed as policy tradeoffs. In other words, inflation and the reduction in commercial banks' overheads may not need to be compromised to preserve transmission, which in itself is not an objective, but a mechanism that helps the central bank to achieve its priority goals. Instead, any weakening of pass-through owing to successful disinflation or reduced overhead costs could be compensated through other means, such as strengthening competition, mopping up excess liquidity (if any), improving credit quality and developing financial markets to reduce interest rate volatility. 


\section{References}

Bank for International Settlements, 1998, “The Transmission of Monetary Policy in Emerging Market Economies,” BIS Policy Papers No. 3 (Basel, Switzerland).

Bernanke, S. B., and M. Gertler, 1995, “Inside the Black Box: The Credit Channel of Monetary Policy Transmission,” The Journal of Economic Perspectives, Vol. 9, No. 44, pp. 27-48.

Borio, C. E.V., and W. Zritz, 1995, “The Response of Short-term Bank Lending Rates to Policy Rates: A Cross-Country Perspective,” BIS Working Paper No. 27 (Basel, Switzerland: Bank for International Settlements).

Coricelli, F., B. Egert, and R. McDonald, 2006, "Monetary Transmission in Central and Eastern Europe: Gliding on a Wind of Change," Focus on European Economic Integration, 1/06, pp. 44-87 (Vienna, Austria: Oesterreichische Nationalbank).

Coricelli, F., B. Jazbec, and I. Masten, 2003, "Exchange Rate Pass-Through in Acceding Countries: The Role of Exchange Rate Regimes,” CEPR Discussion Paper 3894 (Washington: Centre for Economic Policy Research).

Cottarelli, C., G. Ferri, and A. Generale, 1995, "Bank Lending Rates and Financial Structure in Italy: A Case Study,” IMF Working Paper WP/95/38 (Washington: International Monetary Fund.

Cottarelli, C., and A. Kourelis, 1994, "Financial Structure, Bank Lending Rates and the Transmission Mechanism of Monetary Policy,” IMF Working Paper WP/94/39 (Washington: International Monetary Fund).

DeBondt, G., 2002, "Retail Bank Interest Rate Pass-Through: New Evidence at the Euro Area Level,” ECB Working Paper 136 (Frankfurt, Germany: European Central Bank).

DeBondt, G., B. Mojon, and N. Valla, 2005, “Term Structure and Sluggishness of Retail Bank Interest Rates in Euro Area Countries,” ECB Working Paper 518 (Frankfurt, Germany: European Central Bank).

Egert, B., and R. MacDonald, 2009, "Monetary Transmission Mechanism in Central and Eastern Europe: Surveying the Surveyable,” Journal of Economic Surveys, 23(2), pp.277327.

Egert, B, J. Crespo-Cuaresma, and T. Reininger, 2007. “Interest Rate Pass-Through in Central and Eastern Europe: Reborn from Ashes Merely to Pass Away,” Journal of Policy Modeling, Elsevier, vol. 29(2), pages 209-225

Gambacorta, L., 2004, “How Do Banks Set Interest Rates?” NBER Working Paper Series No. 10295 (Cambridge, Massachusetts: National Bureau of Economic Research). 
Gigineishvili, N., 2008, "In Search of Monetary Transmission in Moldova," Republic of Moldova: Selected Issues, IMF Country Report 08/134 (Washington: International Monetary Fund).

Horvath, C., J. Kreko, and A. Naszodi, 2005, "Interest Rate Pass-Through: the Case of Hungary,” Magyar Nemzeti Bank Working Paper 2004/8 (Budapest, Hungary: Magyar Nemzeti Bank).

Imam, P., 2009, “Exchange Rate Choices of Microstates,” IMF Working Paper WP/10/12 (Washington: International Monetary Fund).

International Monetary Fund, 2009, Annual Report on Exchange Arrangements and Exchange Restrictions (Washington).

Mishkin, F. S., 1996, “The Channels of Monetary Transmission: Lessons for Monetary Policy,” Banque de France, Bulletin: Digest No. 27, pp. 33-44.

Mishra, P., P. M. Montiel, and A. Spilimbergo, 2010, "Monetary Transmission in Low Income Countries," IMF Working Paper WP/10/223 (Washington: International Monetary Fund).

Mojon, B., 2000, "Financial Structure and the Interest Channel of the ECB Monetary Policy,” ECB Working Paper No. 40 (Frankfurt, Germany: European Central Bank).

Sander, H., and S. Kleimeier, 2004a, "Convergence in Euro-zone Retail Banking? What Interest Rate Pass-through Tells Us About Monetary Policy Transmission, Competition and Integration,” Journal of International Money and Finance, 23(3), pp. 461-492.

Sander, H., and S. Kleimeier, 2004b, “Interest Rate Pass-through in an Enlarged Europe: the Role of Banking Market Structure for Monetary Policy Transmission in Transition Economies,” METEOR Research Memoranda No. 045, University of Maastricht (Netherlands).

Sander, H., and S. Kleimeier, 2006, "Interest Rate Pass-through in the Common Monetary Area of the SACU Countries,” METEOR RM/06/023, University of Maastricht (Netherlands).

Saunders, A., and L. Schumacher, 2000, "The Determinants of Bank Interest Rate Margins: an International Study,” Journal of International Money and Finance, 19, pp. 813-832.

Sorensen, C.K., and T. Werner, 2006, "Bank Interest Rate Pass-through in the Euro Area: A Cross Country Comparison,” ECB Working Paper No. 580 (Fankfurt, Germany: European Central Bank).

Weth, M.A., 2002, "The Pass-through from Market Rates to Bank Lending Rates in Germany,” Deutsche Bundesbank Discussion Paper 11/02 (Mainz, Germany: Deutsche Bundesbank). 